\title{
カラオケ歌唱による声質変化と水分摂取の関係
}

\author{
足立 千浪 ${ }^{1)}$ 吐師 道子 ${ }^{2)}$ 城本 修2) 土師 知行 ${ }^{2)}$
}

要 約: カラオケ歌唱による声質変化の有無, 声質変化と水分摂取の関係を解明するため 1) 16 曲のカラオケ歌唱はその後の音声の jitter ・ shimmer · harmonic-to-noise ratio (HNR) に 変化をもたらすか, 2) カラオケ歌唱中の水分摂取の有無はカラオケ後の音声の jitter · shimmer・HNR の変化程度に差をもたらすかを検討した。その結果, 16 曲のカラオケ歌唱は その後の低い声と出しやすい声の高さの発声に影響を及ぼすことが示された。しかしVEによ る喉頭所見では炎症や血腫等の著明な変化は見られず, カラオケ後の音響特徵の変化が血腫等 に起因するものではない可能性が示唆された。また，声の高さやパラメー夕を通じた水分摂取 の効果は見られなかったが, 高い声での発声が水分摂取の有無に敏感である可能性が示唆され た。

索引用語：音声疲労，カラオケ，水分摂取，音響分析

\section{Voice Quality Changes after Karaoke and Effects of Hydration}

\author{
Chinami Adachi ${ }^{1)}$, Michiko Hashi' ${ }^{2}$, Osamu Shiromoto ${ }^{2)}$ and Tomoyuki Haji ${ }^{2)}$
}

\begin{abstract}
The present study investigated 1) whether singing sixteen songs in karaoke results in changes in videoendoscopic observation or in jitter, shimmer and/or harmonic-tonoise ratio (HNR) in speech, and 2) whether water intake during karaoke has effects on the above changes. The results indicated that karaoke singing had an effect on jitter, shimmer and HNR in the vowel /a/ when produced in a low and comfortable pitch. No signs of inflammation or edema were found in the videoendoscopic observations. There was no consistent effect of water intake across all pitch conditions and voice perturbation measures; however, jitter and HNR showed effects of water intake in the high pitch condition, suggesting that high-pitched voices may be sensitive to the presence or absence of water intake during singing.
\end{abstract}

Key words: vocal fatigue, karaoke, hydration, stroboscopy

医療法人珪山会鵜飼リハビリテーション 病院 ${ }^{1)}$ ：干453-0811 愛知県名古屋市中村区太閤通 4-1

県立広島大学保健福祉学部コミュニケーション障害学科 ${ }^{2)}$ ： †723-0053 広島県三原市学園町 1-1

${ }^{1)}$ Ukai Rehabilitation Hospital: 4-1, Taiko-tori, Nakamura-ku, Nagoya, Aichi 453-0811, Japan

${ }^{2}$ Department of Communication Sciences and Disorders, Prefectural University of Hiroshima: 1-1 Gakuen-cho, Mihara, Hiroshima 723-0053, Japan

2013 年 12 月 16 日受稿 2014 年 2 月 12 日受理 


\section{はじめに}

カラオケの普及に伴い, カラオケポリープなど無理 な歌唱による声帯の問題が報告され ${ }^{1)}$ カラオケ歌唱が 声質変化を起こす可能性が示唆されている. カラオケ 後の音声の音響特徵の変化について, 石岡 2 ( 15 曲 のカラオケ歌唱は声の聴覚的印象抒よび shimmer, NHR に影響を及ぼすと報告している。しかし Yiu は約 100 分の歌唱では母音の jitter および shimmer に変化は見られないとしており, 先行研究間で一致す る結果は得られていない.

一方, 声の衛生指導では, 声带保湿はPTP (Phonation Threshold Pressure) に影響するとされ, 声帯保護のため発声時の水分摂取が推奨されてい る ${ }^{4)}$. $\mathrm{Yiu}^{3)}$ は水分摂取によってより長く歌唱が可能で あるとしている。しかし声質変化に伴う音響特徵の変 化に対する水分摂取の影響は検討されておらず，カラ オケ歌唱による音声疲労に対する水分摂取の影響は十 分に解明されていない.

本研究では声質変化の音響的関連量である jitter (F0巾らぎ) · shimmer（振幅ゆらぎ）・HNR（調波 対雑音比）に着目し, カラオケ歌唱のこれらの音響的 特徵への影響と, これに対する水分摂取の影響を検討 した，本研究の目的は 1）16曲のカラオケ歌唱はその 後の音声の jitter · shimmer ・ HNR に変化をもたらす か，2）カラオケ歌唱中の水分摂取の有無は音声の jitter · shimmer · HNR の変化程度に差をもたらすか, の検討である.

\section{方法}

\section{1. 被験者}

声楽の素養がなく, 音声障害・声帯疾患のない, 健 康状態良好な女性大学生 8 名（平均年齢 22 歳）とし, 文書にて同意を得た。

\section{2. 実験に使用した曲}

2005 年以降のカラオケランキング5, 6) 上位曲中, 事 前アンケートにて被験者全員が歌えるとした曲のなか から,「さくらんぼ/大塚愛」「ハナミズキ/一青窈」「タッ チ/岩崎良美」「粉雪/レミオロメン」「気まぐれロマン ティックルきものがかり」「ムーンライト伝説/ DALI」「アゲ八蝶/ポルノグラフィティ」「Best Friend/Kiroro」の 8 曲（スローテンポ 4 曲, アップ テンポ 4 曲）を選択した.

\section{3. 実験環境}

カラオケ歌唱実験は, 広島県三原市内のカラオケ
ボックスにて行った。 カラオケボックスは実験中, 室 温 $25 \sim 30^{\circ} \mathrm{C}$, 湿度 $40 \%$ 以上に保たれた。 カラオケの 音量は, 被験者をカラオケボックス内の定位置に座ら せた状態で，実験に使用する「さくらんぼ/大塚愛」 の最初の 1 フレーズの音量が被験者の右耳の位置で 72〜76 dBA (fast 特性) になるように統一した.

\section{4. 手続き}

カラオケ歌唱実験に先立ち，被験者は温度 25 $30^{\circ} \mathrm{C}$, 湿度 $40 \%$ 以上に保った部屋で 30 分間待機した。 待機中は水分摂取 ・必要最低限度以上の声の使用を禁 止した. 待機後カラオケボックスに移動し, 8 曲を 2 回, 合計 16 曲を歌唱させた。

\section{5. 録音}

音声の録音はカラオケボックスにて, カラオケ開始 直前, 8 曲歌唱終了後, 16 曲歌唱終了後の計 3 回行わ れた。 カラオケルームの NCレベルはNC-35（静かな 部屋レベル）であった。

録音は単一指向性コンデンサーマイク（Blue Microphones Snowball）をノートPCに接続し, サン プリング周波数 $44,100 \mathrm{~Hz}$, 量子化ビット数 16 ビット で行った。唇とマイクの距離は $6 \mathrm{~cm}$ とし, / a: / 発 声の際, マイクの位置で $80 \mathrm{dBA}$ 程度の強さで発声さ せ, 声質特徽計測の信頼性妥当性が保障される $\mathrm{SN}$ 比 $30 \mathrm{~dB}$ を確保した7).

\section{6. 発話材料および発話課題}

文章の音読，最も低い声（Low）での/a:/ 発声（3 秒程度) $\times 10$ 回, 出しやすい声の高さ (Comf. ) での/a:/ 発声 $(3$ 秒程度 $) \times 10$ 回, 地声の範囲内の最も高い声 (High) での/a:/ 発声 (3 秒程度 $) \times 10$ 回, 最長母音 発声（出しやすい声の高さで, なるべく長い間 /a:/ と発声する）の 5 項目について録音を行った。 Low, Comf., High 条件の録音順は録音 1 回目, 2 回目, 3 回目でカウンターバランスした。また, 2 回目以降の Low, Comf., High 条件の録音では 1 回目の各条件の 録音音声を聴かせ, 同程度の高さで発声するように教 示した。本研究では Low, Comf., High 条件での/a:/ 発声データを分析対象とした。

\section{7 . 歌唱条件}

歌唱条件は水分摂取, 水分非摂取, コントロールの 3 条件とし, カラオケ歌唱は水分摂取, 水分非摂取の 2 条件で行った。水分摂取条件では, 水 $100 \mathrm{cc}$ を 4 曲 終了後, 2 回目の録音終了後, 12 曲終了後の計 3 回摂 取させ，水分非摂取条件では 16 曲歌唱中水分を摂取 させなかった。コントロール条件ではカラオケ歌唱を せず，音声の録音のみを行った。コントロール条件の 
録音はカラオケ歌唱実験とほほ同じ時間帯に 45 分間 隔で 3 回実施した。被験者は 1 回目の録音開始 30 分 前から録音終了まで温度 $25 \sim 30^{\circ} \mathrm{C}$ ，湿度 $40 \%$ 以上の 室内で過ごし，録音開始 30 分前から 3 回目の録音終 了まで水分摂取を禁止した。

各被験者は，2011 年 8 月 27 日～9 月 30 日の間，1 日 1 条件計 3 日間実験に参加した。水分摂取条件，水 分非摂取条件間ではカウンターバランスをとり，被験 者の半数は水分摄取条件，水分非摂取条件の順に，半 数は水分非摂取条件，水分摂取条件の順に実験を行っ た。 また，水分摂取条件，水分非摂取条件の実験は最 低 7 日の間隔を空けて行った。

\section{8. videoendoscopy (VE)}

被験者 8 名のなかから無作為に選択した 4 名につい て, カラオケ歌唱前 (30 分の待機終了後), およびカ ラオケ歌唱終了後の 2 回, VEによる喉頭観察, 記録 を行った，観察および記録にはオリンパスメディカル システムズ社（株）VISERA耳鼻咽喉ビデオスコー プ OLYMPUS ENF TYPE V2を使用した。 また，永 島医科器械（株）ストロボスコープ LS-3Aを使用し, ストロボスコープによる声帯振動の観察も行った.

\section{9. 音響分析}

音響分析ソフトゥェア Praat ${ }^{8)}$ を用い, /a:/ 発声に ついてF0, jitter, shimmer, HNR を計測した，F0 計測結果は狭帯域スペクトログラムによって確認し, 計測值が一致しない部分は分析から除外した。

\section{0. 統計処理}

jitter, shimmer, HNRの 3 つの音響パラメータと Low, Comf., High 条件の 3 条件による計 9 の組み合 わせについてそれぞれ，歌唱条件，録音回数，被験者 を要因とする 3 要因の分散分析を行った。 jitter, shimmerについては，逆 $\sin$ 変換した值を分析に使用 した。なお， jitter, shimmer, HNR という3つ音響 パラメータと Low, Comf., High という3つの声の 高さによる計 9 の組み合わせは以降，表 1 のように表 記する。

表 1 音響パラメータと声の高さ条件の組み合わせの表記

\begin{tabular}{|c|c|c|c|}
\hline $\begin{array}{rr}\text { 声の高さ } \\
\text { パラメータ } \\
\text { 条件 }\end{array}$ & Low & Comf. & High \\
\hline jitter & $\begin{array}{l}\text { Low- } \\
\text { jitter }\end{array}$ & $\begin{array}{l}\text { Comf- } \\
\text { jitter }\end{array}$ & $\begin{array}{l}\text { High- } \\
\text { jitter }\end{array}$ \\
\hline shimmer & $\begin{array}{c}\text { Low- } \\
\text { shimmer }\end{array}$ & $\begin{array}{c}\text { Comf- } \\
\text { shimmer }\end{array}$ & $\begin{array}{c}\text { High- } \\
\text { shimmer }\end{array}$ \\
\hline HNR & Low-HNR & Comf-HNR & High-HNR \\
\hline
\end{tabular}

\section{結果}

\section{1. カラオケ歌唱の声質への影響}

以下の基準のいずれかを満たした場合，カラオケ歌 唱の声質への影響が認められると判断した。

1 ）歌唱条件, 録音回数, 被験者を要因とする 3 要 因の分散分析において歌唱条件の主効果が有意であ り，下位検定（Scheffe）で jitter， shimmerでは水分 摂取条件または水分非摂取条件のいずれかがコント ロール条件より高くなった場合，HNRでは水分摂条 件取または水分非摂取条件のいずれかがコントロール 条件より低くなった場合。

2 ) 条件の主効果は有意ではないが，回数と条件の 交互作用が有意であり，コントロール条件では 1 3 回目の結果に明らかな変化がなく，水分摄取条件また は水分摂取条件では録音回数の増加に伴い, jitter, shimmer では上昇傾向，HNR では下降傾向が見られ た場合.

3 音響パラメータ $\times 3$ つの声の高さ条件の計 9 の組 み合わせのうち，基準 1）を満たした組み合わせは Low-jitter, Low-shimmer, Low-HNR, Comf. shimmer，High-HNR であり，基準 2）を満たした組 み合わせはこれらに加え Comf.-jitter, Comf.-HNR で あった，Low-jitter, Low-shimmer, Low-HNR の 結 果を図 1〜3に示す。

Low-jitter（図 1）はすべての主効果, すべての要 因間の交互作用が有意であった $(\mathrm{p}<0.05)$ ，コントロー

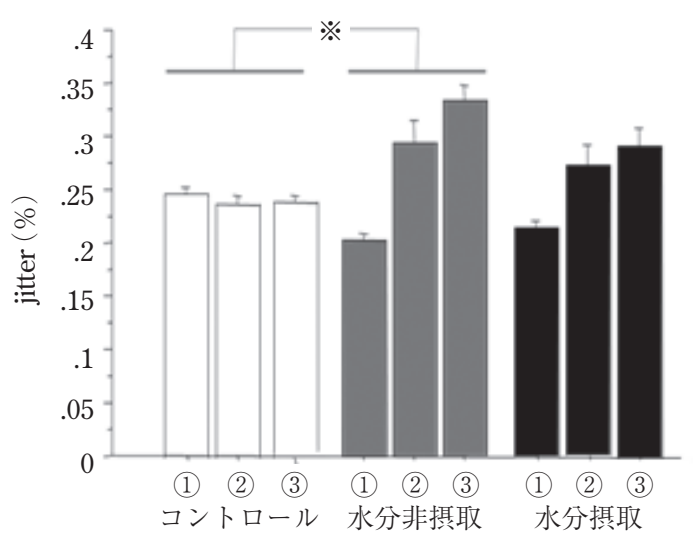

図 1 Low-jitter：歌唱条件および録音回数別 jitter ％）平均值。縦軸は\%jitter，横軸は歌唱条 件と録音回数を表す。歌唱条件は左からコ ントロール条件, 水分非摂取条件, 水分摂 取条件を表し, 録音回数は(1)は録音 1 回目, (2)は 2 回目, (3) 3 回目を表す。※は下位 検定（Scheffe）にて条件間で有意差が見ら れた比較を示す $(\mathrm{p}<0.05)$. 


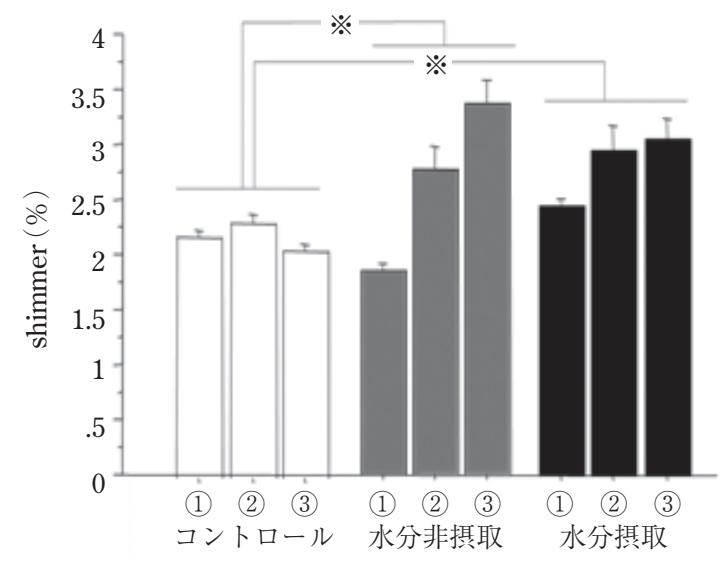

図 2 Low-shimmer：歌唱条件および録音回数別 shimmer（\%) 平均值。縦軸は \%shimmer，横 軸は歌唱条件と録音回数を表す。歌唱条件は 左からコントロール条件, 水分非摂取条件, 水分摂取条件を表し, 録音回数は(1)は録音 1 回目, (2) 2 回目, (3)は 3 回目を表す。※は 下位検定 (Scheffe) にて条件間で有意差が見 られた比較を示す $(\mathrm{p}<0.05)$.

ル条件より水分非摂取条件で jitterが高く,歌唱を行っ た条件での声質の悪化を認めた $(\mathrm{p}<0.05)$ ．また歌唱 条件と録音回数の交互作用が有意であり $(\mathrm{p}<0.05)$, コントロール条件では録音回数によって jitter に明ら かな変化はないが, 水分摂取条件と水分非摂取条件で は録音回数の増加に伴い上昇傾向が見られた。

Low-shimmer（図 2）はすべての主効果，すべての 要因間の交互作用が有意であった $(\mathrm{p}<0.05)$. コント ロール条件より水分非摂取条件, 水分摂取条件で shimmer が高く, 歌唱を行った条件での声質の悪化 を認めた $(\mathrm{p}<0.05)$. また, 歌唱条件と録音回数の交 互作用が有意であり $(\mathrm{p}<0.05)$ ，コントロール条件で は録音回数によって shimmer に明らかな変化はない が, 水分摂取条件と水分非摂取条件では録音回数の増 加に伴い上昇傾向が見られた.

Low-HNR（図 3）はすべての主効果, すべての要 因間の交互作用が有意であった $(\mathrm{p}<0.05)$ ，コントロー ル条件より水分非摂取条件, 水分摂取条件で HNR が 低く, 歌唱を行った条件での声質の悪化を認めた（p $<0.05)$. また歌唱条件と録音回数の交互作用が有意 であり $(\mathrm{p}<0.05)$ ，コントロール条件では録音回数に よって HNRに明らかな変化はないが，水分摂取条件 と水分非摂取条件では録音回数の増加に伴い下降傾向 が見られた。

Comf.-shimmer, High-HNR もすべての主効果, す べての要因間の交互作用が有意であった $(\mathrm{p}<0.05)$.

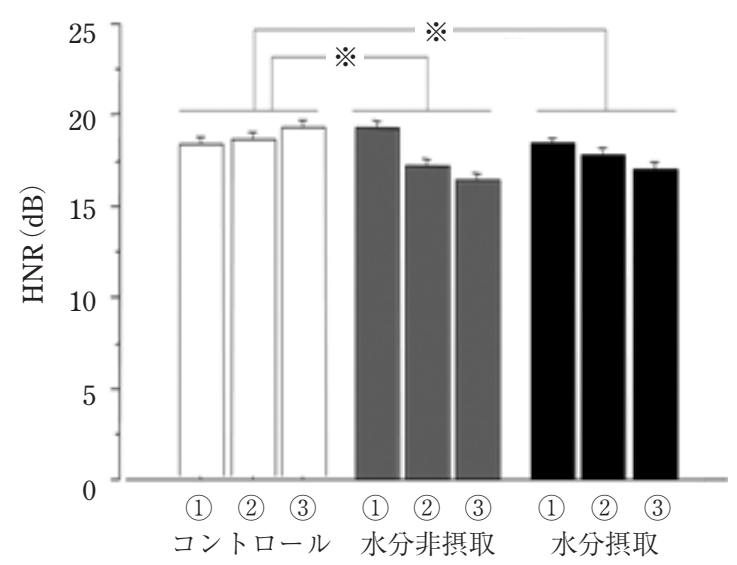

図 3 Low-HNR：歌唱条件および録音回数別 HNR (dB) 平均值。縦軸は $\mathrm{dB} H \mathrm{HN}$, 横軸は歌唱条 件と録音回数を表す。歌唱条件は左からコン トロール条件, 水分非摂取条件, 水分摂取条 件を表し, 録音回数は(1)は録音 1 回目, (2)は 2 回目, (3) 3 回目を表す。※は下位検定 (Scheffe) にて条件間で有意差が見られた比較 を示す $(\mathrm{p}<0.05)$.

Comf.-shimmer ではコントロール条件より水分非摂取 条件, 水分摂取条件で shimmer が高く, High-HNR ではコントロール条件より水分非摂取条件で HNR が 低く, 歌唱を行った条件での声質の悪化を認めた（p $<0.05)$.

Comf.-jitter, Comf.-HNR は録音回数, 被験者の主 効果, すべての要因間の交互作用が有意であった（p <0.05). Comf.-jitter では歌唱条件と録音回数の交互 作用が有意であり $(\mathrm{p}<0.05)$ ，コントロール条件では 録音回数により明らかな变化はないが, 水分非摂取条 件で録音回数の増加に伴い jitter の上昇傾向が見られ た. Comf.-HNRにおいても歌唱条件と録音回数の交 互作用が有意であり $(\mathrm{p}<0.05)$ ，コントロール条件で は録音回数によって HNR に明らかな変化はないが, 水分摂取条件と水分非摂取条件では録音回数の増加に 伴い下降傾向が見られた.

歌唱の影響についての結果を表 2 に示す。低い声と 出しやすい声の高さの発声では, jitter, shimmer, HNR のすべてで歌唱の影響が認められた。

\section{2. 水分摂取の効果}

歌唱条件, 録音回数, 被験者を要因とする 3 要因の 分散分析において歌唱条件の主効果が有意であり，下 位検定 (Scheffe) で jitter, shimmerでは, 水分摂取 条件が水分非摂取条件より高く, HNR では水分摂取 条件より水分非摂取条件が低くなった場合, 水分摂取 の効果ありと判断した。 


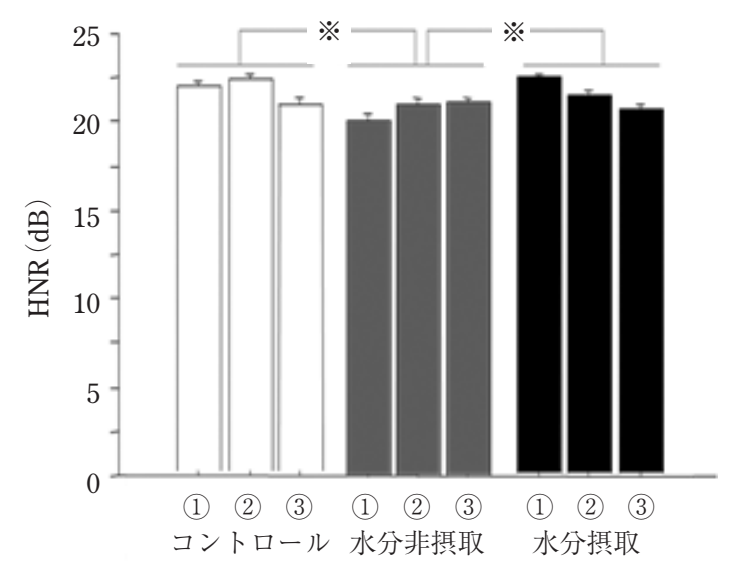

図 4 High-HNR：歌唱条件㧍よび録音回数別 HNR (dB) 平均值。縦軸は $\mathrm{dB} H \mathrm{HNR}$, 横軸は歌唱 条件と録音回数を表す。歌唱条件は左からコ ントロール条件，水分非摂取条件，水分摂取 条件を表し，録音回数は(1)は録音 1 回目，(2) は2 回目, (3) 3 回目を表す。※は下位検定 (Scheffe) にて条件間で有意差が見られた比 較を示す $(\mathrm{p}<0.05)$

3 音響パラメータ $\times 3$ つの声の高さ条件の計 9 の組 み合わせのうち，上記基準を満たした組み合わせは High-jitter, High-HNR であった.

High-HNR（図 4）はすべての主効果, すべての要 因間の交互作用が有意であった $(\mathrm{p}<0.05)$. 水分摂取 条件より水分非摂取条件で HNR が低く，水分摂取に よる声質悪化の軽減を認めた $(\mathrm{p}<0.05)$. High-jitter ではすべての主効果，すべての要因間の交互作用が有 意であった $(\mathrm{p}<0.05)$. 水分摂取条件より水分非摂取 条件で jitter が高く，水分摂取による声質悪化の軽減 を認めた $(\mathrm{p}<0.05)$.

パラメータと声の高さ条件を通しての水分摂取の効 果は見られなかったが，高い声での発声ではjitter， HNR に効果が認められた。なお High-shimmerでは 歌唱の影響も水分摂取の効果も認められなかった.

\section{3. 個人差}

被験者の主効果は 3 音響パラメータ $\times 3$ 声の高さ条 件の計 9 の組み合わせすべてにおいて有意となり（p $<0.05)$ ，歌唱条件抒よび録音回数の各音響パラメー タへの影響には個人差が認められた。

\section{VE}

4 名の VEによる喉頭所見にはカラオケ歌唱前, カ ラオケ歌唱後ともに，また水分摂取条件，水分非摂取 条件いずれの条件に扔いても, 声带の発赤, 腫脹, 血 腫などの異常は認められず，ストロボスコープによる 観察でも，はっきりした声帯振動の変化は見られな
表 2 歌唱の影響があった組み合わせ

\begin{tabular}{|c|c|c|c|}
\hline $\begin{array}{r}\text { 声の高さ } \\
\\
\text { パラメータ }\end{array}$ & Low & Comf. & High \\
\hline jitter & $\begin{array}{l}\text { 主効果 } \\
\text { 交互作用 }\end{array}$ & 交互作用 & なし \\
\hline shimmer & $\begin{array}{l}\text { 主効果 } \\
\text { 交互作用 }\end{array}$ & 主効果 & なし \\
\hline HNR & $\begin{array}{l}\text { 主効果 } \\
\text { 交互作用 }\end{array}$ & 交互作用 & 主効果 \\
\hline
\end{tabular}

かった。

\section{考察}

音響パラメータと声の高さ条件の 9 の組み合わせの うち, 7 でカラオケ歌唱後に音響特徵の悪化が見られ, 16 曲のカラオケ歌唱はその後の音声の jitter · shimmer・HNRに変化をもたらすことが判明した， 石岡 ${ }^{2)}$ は, 15 曲のカラオケ歌唱がその後の声の聴覚 的印象および, shimmer や NHR といった音響特徵に 影響を及ぼすと報告したが，本研究の結果はこれを支 持するものとなり, jitter, shimmer，HNR な゙に現 れる声質の変化がカラオケという広く行われている㛣 楽で発生することが明らかとなった。特に低い声での 発声ではすべてのパラメータで主効果抒よび交互作用 が有意，出しやすい声ではすべてのパラメータで主効 果または交互作用が有意であり，カラオケによる声質 変化は特に低い声と出しやすい声の高さで出現するこ とが明らかになった。

半数の被験者に実施したVEによる喉頭所見では, 歌唱後には発赤, 腫脹, 血腫の出現などの明らかな変 化は見られず，声帯振動についても特に変化が見られ なかったことから，通常の耳鼻咽喉科診察で声帯に明 らかな異常を認めなくても, カラオケ後の音声の音響 特徵の変化が起こりうることが示された。また本研究 の結果は西尾 ${ }^{9)}$ が報告した成人女性の jitter\%, shimmer\% と比較して低く，本研究で観察された変化 は正常範囲内の変化であると考えられる。しかし本研 究の 2 カラオケ歌唱条件は 1 週間の間隔をおいて実施 されており，実施時間も45分程度であり，本研究の 結果から長時間かつ高頻度のカラオケ歌唱を繰り返し た場合の変化の予測は困難である。頻繁に長時間のカ ラオケ歌唱を行った場合，また，歌唱にアルコール摂 取が伴う場合などでは健常範囲を超える変化が出る可 能性は捨てきれず，カラオケヘビーユーザーにおける 声質変化は今後も追跡されるべきであろう。 
カラオケ歌唱による声質変化への水分摂取の影響は 音響パラメータと声の高さ条件の組み合わせ 9 のうち 2 で観察され，この 2 つの組み合わせはいずれも High 条件であった，音響パラメータや声の高さ条件 を通じた水分摂取の効果は見られなかったが，高い声 での発声は水分摂取の有無に特に敏感である可能性が 考えられ，音声疲労研究において，声の高さを考慮す る必要性を示唆している。

\section{文献}

1）三瀬和代, 田口亜紀，豊島真理子，他：声帯結節に対する 音声治療の臨床的検討。 日本音声言語医学, 49:52-53, 2008.

2) 石岡佐織, 山口宏也, 羽生燿子 : カラオケ前後の声質の変 化. 音声言語医学, $41: 61,2000$.

3) Yiu EM and Chan RM: Effect of hydration and vocal rest on the vocal fatigue in amateur karaoke singers. J Voice, 17: 216-227, 2003.
4）城本 修：言語聴覚士の立場から一音声治療の効果に関す るエビデンス一. 音声言語医学, $50 ：$ 136-143, 2009.

5) JOYSOUND : カラオケ年間ランキング, http://joysound. com/ex/ranking/karaoke/ total/year.htm

6）うたウガ POWERED by UGA : 年別カラオケランキング, http://utauga.jp/ranking/rank_year.php

7) Deliyski DD, Shaw HS and Evans MK: Adverse effects of environmental noise on acoustic voice quality measurements. J Voice, 19 (1): 15-28, 2005.

8) Boersma P and Weenink D: Praat: doing phonetics by computer (Version 5.2.35) [Computer program], http:// www.praat.org/ (2010 年)

9）西尾正輝, 田中康博, 新美成二：加齢に伴う音声の変化一 音響的手法を用いた解析一, 音声言語医学, $50: 6-13$, 2009.

別刷請求先 : $\bar{T} 723-0053$ 広島県三原市学園町 1-1 県立広島大学保健福祉学部コミュニケーション 障害学科

吐師道子 